University for Business and Technology in Kosovo

UBT Knowledge Center

Oct 27th, 9:00 AM - 10:30 AM

\title{
Dynamics of improvement of some physico-chemical parameters in Lumbardhi River of Prizren from urban water discharges for the year 2018 compared to the year 2017
}

\author{
Sami Gashi \\ University for Business and Technology, sami.gashi@ubt-uni.net \\ Besa Beseli \\ University for Business and Technology, besa.veseli@ubt-uni.net \\ Petrit Drini \\ Factory of Zinc Galvanism, petritdrini@yahoo.com
}

Follow this and additional works at: https://knowledgecenter.ubt-uni.net/conference

Part of the Engineering Commons

\section{Recommended Citation}

Gashi, Sami; Beseli, Besa; and Drini, Petrit, "Dynamics of improvement of some physico-chemical parameters in Lumbardhi River of Prizren from urban water discharges for the year 2018 compared to the year 2017" (2018). UBT International Conference. 144.

https://knowledgecenter.ubt-uni.net/conference/2018/all-events/144

This Event is brought to you for free and open access by the Publication and Journals at UBT Knowledge Center. It has been accepted for inclusion in UBT International Conference by an authorized administrator of UBT Knowledge Center. For more information, please contact knowledge.center@ubt-uni.net. 


\title{
Dynamics of improvement of some physico-chemical parameters in Lumbardhi River of Prizren from urban water discharges for the year 2018 compared to the year 2017
}

\author{
Gashi Sami ${ }^{1}$, Besa Veseli ${ }^{2}$ Drini Petrit ${ }^{3}$ \\ ${ }^{1}$ College UBT, Prishtinë; e-mail: sami.gashi@ubt-uni.net \\ ${ }^{2}$ College UBT, Prishtinë; e-mail: besa.veseli@ubt-uni.net \\ ${ }^{3}$ Factory of Zinc Galvanism, Prizren, \\ e-mail: petritdrini@yahoo.com
}

\begin{abstract}
The rapid growth of our city Prizren and urban problems, especially those of sewage, resulted in the pollution of the Lumbardhi River, since urban wastewater was not treated in advance until the year 2017, therefore in 2018 the collectors were built aimed at mitigating river pollution. Therefore, the purpose of the paper is to compare and evaluate some basic physico - chemical pollution indicators without treatment of urban waste water in 2017 with those treated with collectors of the year 2018 .

The physico - chemical parameters to be treated are: Content of Dissolved Solid Substances in Water (DSS) that limits the use of water for irrigation and industrial purposes, BOD5 level that is not suitable for the life of living things that require oxygen, Chemical Oxygen Demand (COD) that is a parameter which is used to measure the content of organic substances in urban and industrial water remains, and the total organic carbon (TOC). The monitoring points of the physical and chemical analyzes in our study in Lumbardhi are: Entrance to the city - Marashi (L1), City Center - Municipal Assembly (L2) and City Suburb - Vlashnje (L3).
\end{abstract}

Keywords: Dissolved Suspensive Substances (DSS), Biochemical Oxygen Demand/Consumption (BOD5), Chemical Oxygen Demand (COD), Total Organic Carbon (TOC).

\section{Introduction}

The Lumbardhi River of Prizren has leakage of the mountain river, which by 2017 has no municipal and industrial wastewater treatment plants. Urban waters are one of the main pollutants of surface and underground waters. Treatment of urban and industrial discharged waters in Prizren practically started in 2018, initially with the construction of collectors.

So our city is also expecting big obligations, especially in relation to the fulfillment of the EU directives (Directive 91/271 / EEC on Urban Wastewater Treatment) and the fulfillment of other international obligations. Therefore, the municipality of Prizren currently has a strategy for wastewater management and the creation of functional mechanisms by building a sewage treatment plant which will be completed in 2018/19 and then I believe that with regard to urban discharges in the future we will have an excellent performance without pollution. So in this paper we are examining the Lumbardhi - River pollution based on the physico - chemical parameters of the discharge waters during the same time intervals May - June for different years (2017 2018). 


\section{Material and methods}

In our study we have sampled in places where there is more noticeable urban pollution. Entries to the City - Marashi (L1), City Center - Municipal Assembly (L2) and city Suburb - Vlashnje (L3). Monitoring of Lumbardhi's pollution was done at intervals of time: May-June 2017 and 2018, taking average values from these Lumbardhi sampling sites and compare them. The methods applied in the physico-chemical analyzes of water quality at the monitoring points are based on the European Union guidelines for the quality of surface waters. Based on the maximum allowed values of WHO (World Health Organization), the comparison of their physico-chemical values with the values obtained from our laboratory analyzes is presented in the tables and diagrams.

\subsection{Sample}

Samples for laboratory analyzes for the determination of physical and chemical characteristics of Lumbardhi of Prizren are done at three locations (sampling sites) Figure 1.: Entrance to the city - Marashi (L1), City Center - (L2) and City Suburb Vlashnje (L3).

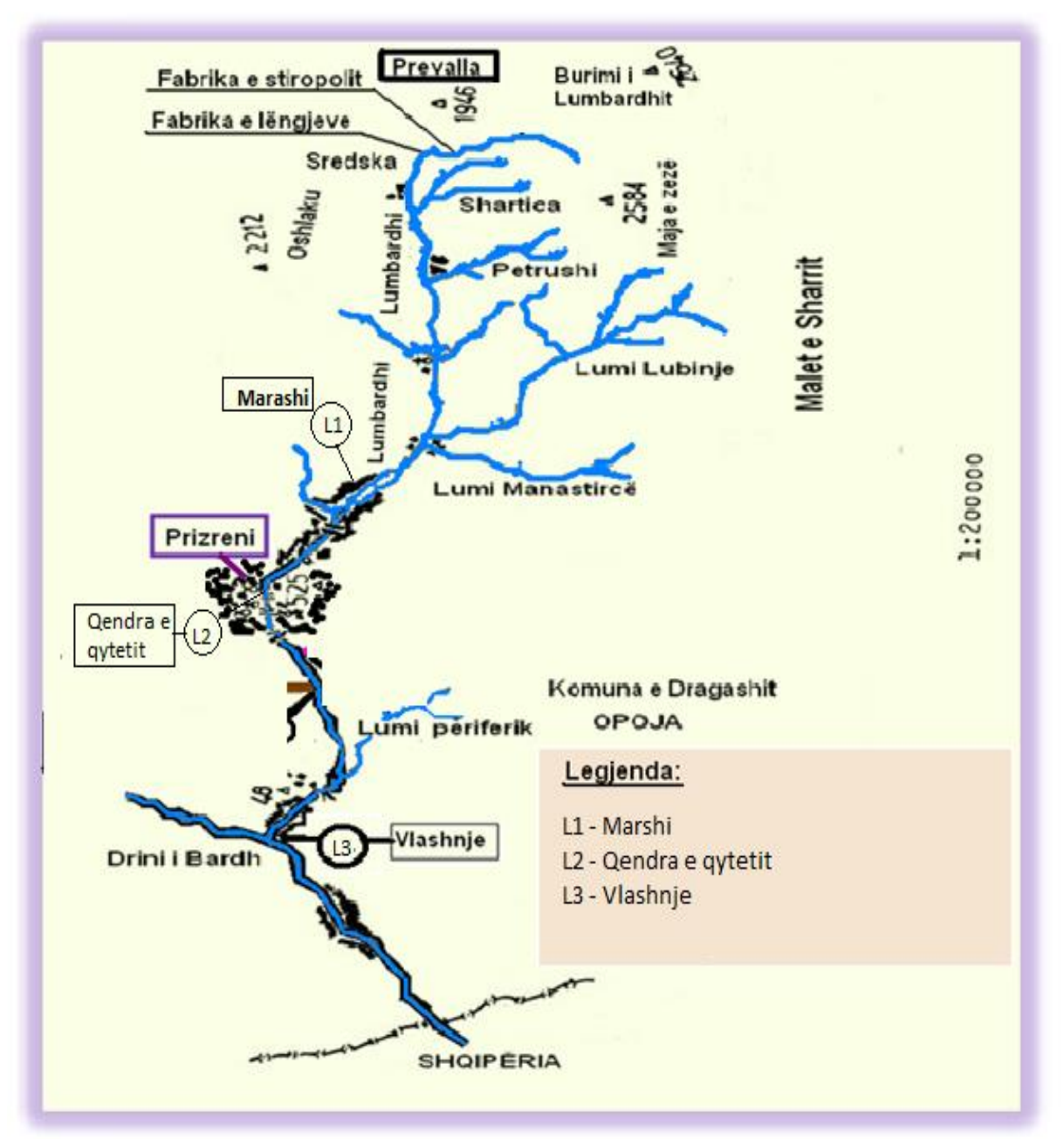

Figure 1. Map of sampling sites 
1. Some general physical and chemical characteristics of urban waste water and their comparison for the year 2017 and 2018 in Lumbardhi of Prizren

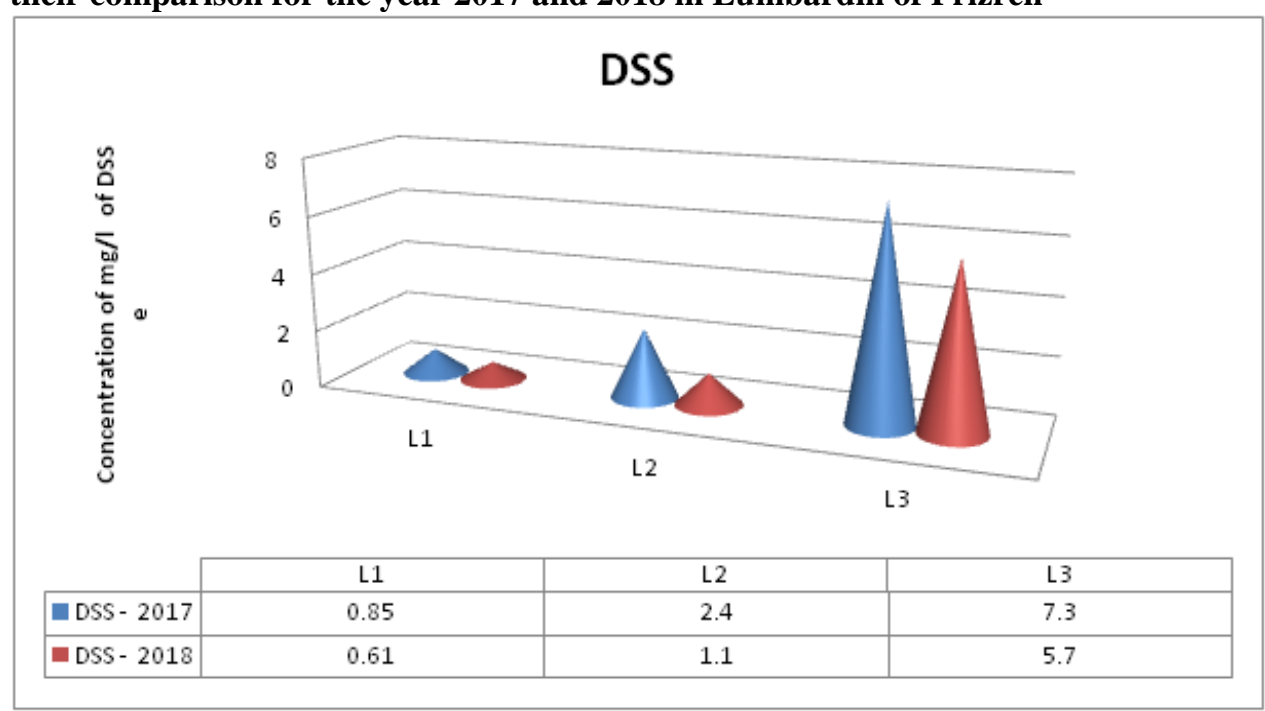

Figure 2. Graphic presentation of concentrations of DSS (dissolved suspensive substances) and their comparison in the time interval $2017-2018$

Referring to the data of 2017 in Figure 2 it is noticed that, apart from the sampling sites: L1 and L2, where the quality of the waters is good, whereas in the L3 sampling site this quality is of low level. This is due to the pollution of water from various sources of pollutants during its flow. At the third sampling site Vlashnje there is a huge increase in DSS which means that there is a serious pollution from the urban liquid discharges. But with the construction of the collectors in 2018 it is noticed that there is a pollution prevention and the values according to Figure 2, show a decrease.

\begin{tabular}{|l|l|l|l|l|l|}
\hline \multicolumn{1}{|c|}{} & \\
\hline
\end{tabular}

Figure 3. Graphic presentation of the COD concentrations (chemical oxygen demand) and their comparison in the time interval $2017-2018$

Referring to the COD indicators for the year 2017 in Figure 3 it is noted that at the sampling sites: L1, the water quality is good, whilst at other monitoring sites L2 and L3 the water quality varies from average to the lower ones. It is noted that the values of the COD indicator are increasing from the first sampling site to the third sampling site, so there is a large increase of COD, which means there is a serious pollution from urban liquids, household discharges. By comparing these values with the values gained in 2018, 
there is a decrease in the pollutant parameters, which means that a collector treatment has an impact on water quality.

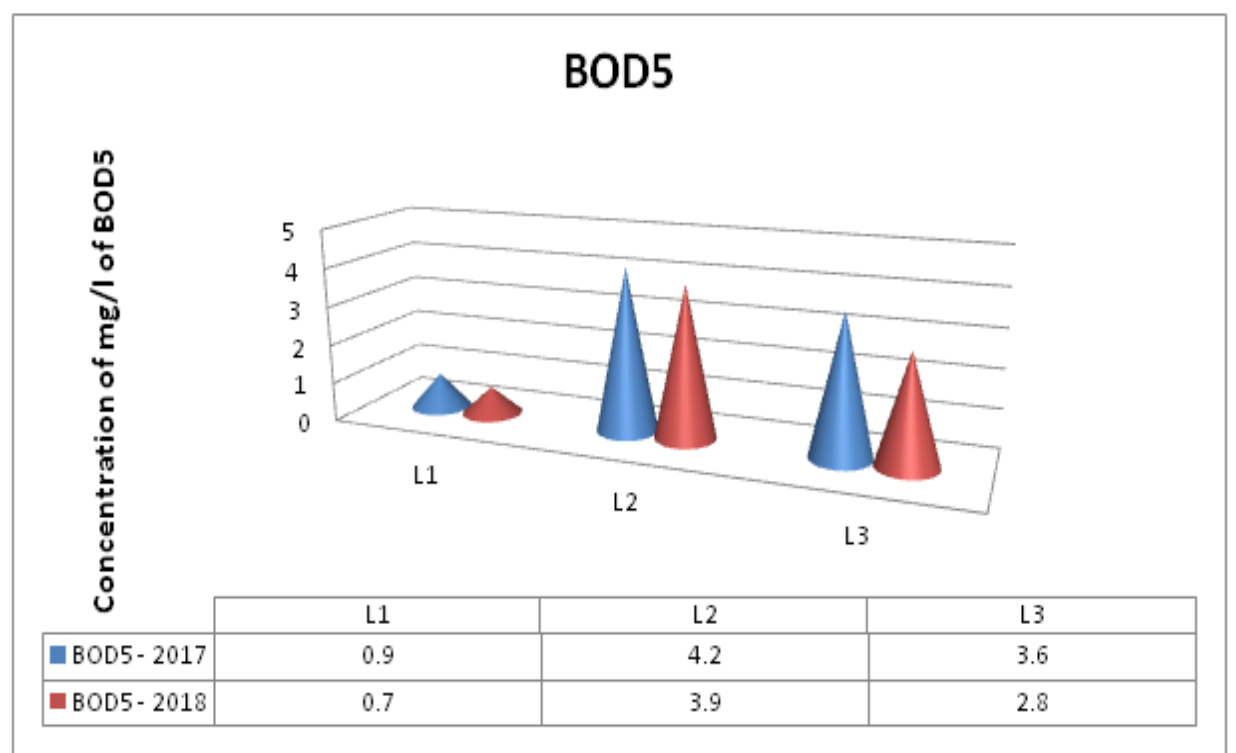

Figure 4. Graphic presentation of BOD5 concentrations (biochemical oxygen demand) and their comparison in the time interval $2017-2018$

Also referring to the data for the year 2017 in Figure 4 it is noticed that, apart from the resources: L1, compared to the sampling site L2 and L3 of the source, where the water quality is good, at the other monitoring sites this quality varies from the values of the higher levels. It is noted that the BOD5 indicator values are increasing from the first to the third sampling sites. But compared with the values gained in 2018, there is a significant increase in BOD5, which means that the construction of the collectors has resulted positively in the prevention of pollution.

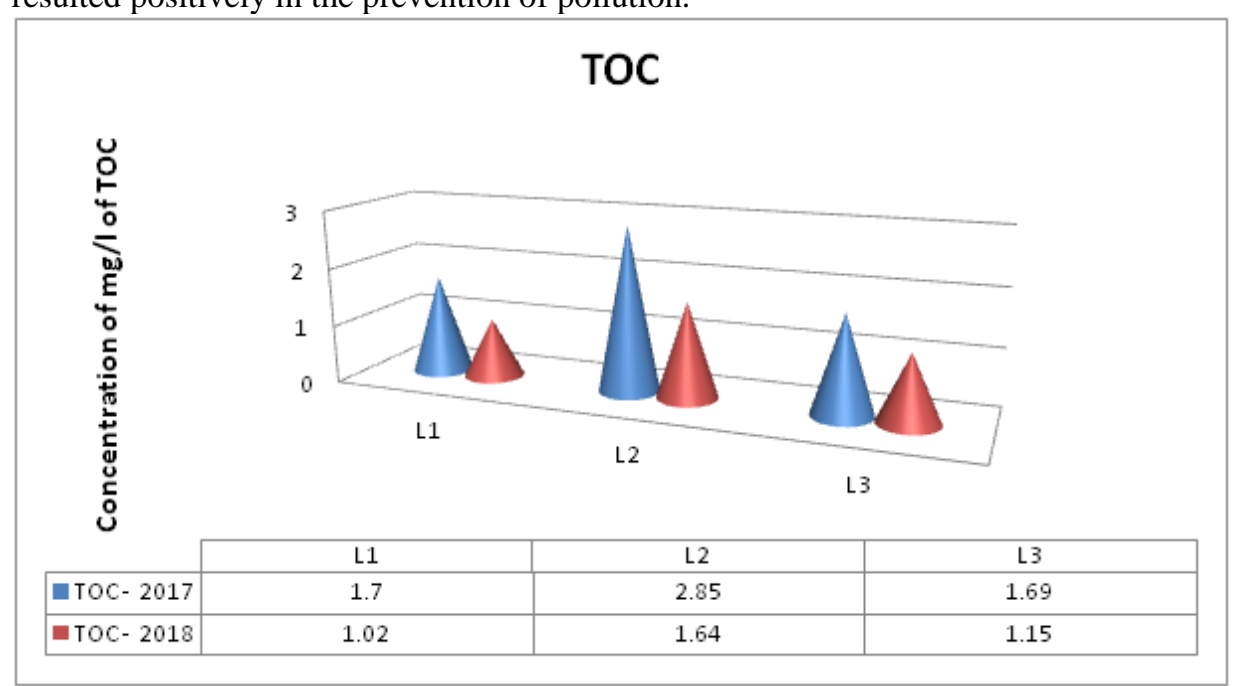

Figure 5. Graphical presentation of concentrations of TOC (Total Organic Carbon) and their comparison in the time interval 2017 - 2018

Referring to the data in Figure 5 it is noted that for the sampling sites: L1, L2 and L3. Total Organic Carbon has improved over the years, compared to water quality between 2017 and 2018, water quality at the monitoring sites has improved significantly. 


\section{Conclusions}

$\downarrow$ Based on the analyzes and the values gained, we think that we have managed to qualitatively determine the pollution of the river Lumbardhi for the year 2017 and the reduction of the pollution by the collectors in the year 2018 .

$\downarrow$ During physical chemical quality analyzes of samples taken at the sampling sites there are variations of DSS, COD, BOD5 and TOC.

Therefore, we think that with this increase of citizen awareness, and the increase of municipal performance, and by finalizing of the Wastewater Plant, our city will no longer have such problems.

So, hopefully we will finally have an important environmental deed.

\section{References}

1. Stanely E. Manahan: Environmental Chemistry, Fourth Edition, Williard Grant Press, Boston (1984).

2. Shakya, Suman K.: "Alarming Trends of River Pollution in Kathmandu, Nepal", A Journal of the Environment, Volume 6, Number 7 . (2001).

3. Abdullah S,: Conditioning ecological and zonal distribution of the Bistrica River makrozoobentosit in Prizren, page 2 - 5. Prizren (1979)

4. Alqi C,: Environmental Chemistry,page 127, 157- 158, 194 - 195. Tirana (2010)..

5. Anonym, Methods Standard ISO 9001: Hydrometeorology, Institute of Kosovo, page 3 - 7, Pristina (2011)

6. Elmaz SH,: Chemical Technology and Environment, page 116, 334 - 335.Tirana , (2009)

7. Nexhat D, : Environmental Chemistry, page 11 - 16. Prishtinë (1998)

8. Sabahidin V,: Sanitary protection Lumbardhi bedding from sewage pollution. Project of the municipalityof Prizren, page 2- 4. Pristina (2011) 